\title{
The Effects of Infant Massage on the Physical Development of Baby in Indonesian Rural Areas
}

\author{
Lusiana Gultom ${ }^{1}$, Renny Sinaga ${ }^{1} \&$ Kandace Sianipar ${ }^{1}$ \\ ${ }^{1}$ Jurusan Kebidanan, Poltekkes Kemenkes Medan, Medan, Indonesia \\ Correspondence: Lusiana Gultom, Jurusan Kebidanan Medan, Poltekkes Kemenkes RI Medan, 20141, Indonesia: \\ Tel: 62-813-9604-5555. E-mail: rumelia.lubina@yahoo.co.id
}

Received: July 10, 2019 Accepted: August 16, 2019 Online Published: August 22, 2019

doi:10.5539/gjhs.v11n10p142 URL: https://doi.org/10.5539/gjhs.v11n10p142

\begin{abstract}
Infant massage has been a long time and common practice, yet investigating this technique in the academic context is still rarely done. Mother in fact plays an important role in ensuring the effectiveness of infant massage, and therefore she is required to learn about it. This research attempts to find out the effects of infant massage training and education on the infant's physical development for mother in rural areas in Indonesia. This study was designed to compare two groups, namely, the first group of 17 mothers with infant massage education and training intervention since the third trimester, and the second group of 17 mothers without intervention. Body weight, body length, circumference of the upper arms, suckling frequency and suckling duration of the babies in the two groups were compared one month after delivery. One month after the group of mothers giving massage to their babies, there were significant differences $(\mathrm{p}<0.05)$ in body weight, body length, suckling frequency of the babies in the two groups, while none for circumference of upper arms and suckling duration. Comparing the effects of massage on babies before and after giving infant massage, there were significant differences in suckling durations and body weight of the babies. Our study suggests that, after receiving an education on infant massage, mothers with babies are recommended to give massage to their babies. Infant massage brings various benefits to the babies, and it can be performed in natural contexts, including in rural setting.
\end{abstract}

Keywords: infant massage, baby development, mother-child interaction, rural setting, Indonesia

\section{Introduction}

The benefits of massage for babies have been long recognized. Massage stimulates babies to have better physical growth and become a powerful stimulus to the early life of a baby (Heath \& Bainbridge, 2004). It also creates a closer mother-infant bonding (Bagshaw \& Fox, 2005). Newborn babies receiving massage are known to make a quickly health recovery when they are sick (Abdallah, Kurdahi, \& Hawwari, 2013).

Since mothers in many cultures are responsible for the well-being and care of their babies, then they could play strategic roles in stunting prevention. The data issued by the World Bank reveal that, in 2013, as many as $37 \%$ of Indonesian children under five years of age or equal to 9 million children suffered from stunting (The World Bank, 2018). The number decreased to $30 \%$ in 2018 (MoH, 2019). The data from the Indonesian Ministry of Health show that most cases of child stunting occur in rural areas.

Mothers should be empowered, among others, through infant massage training. Most existing researchers so far have discussed infant message in the contexts of hospitals or other health facilities. As far as the researcher is concerned, a very few studies have been carried out with regard to discussions on the effects of infant massage to infant growth, and how mothers get involved in the activity in the natural contexts of their daily life. This research is then an attempt to examine the effects of mother's involvement in infant massage in the context of rural areas in Indonesia.

\section{Methods of the Study}

\subsection{Material and Method}

This research, involving 34 mothers having pregnancy in their third trimester, was conducted in the Village of Perlis, an area under the supervision of Tangkahan Durian Health Center, and Pangkalan Brandan, Langkat Regencies, North Sumatra Province in Indonesia. This is a quasi-experimental research (Zaluchu, 2006) by having two groups. The first group, the intervention group, is the mothers who were given infant massage training, a note 
book and leaflet on infant massage. The second group, the non-intervention group, is the mothers who only had note book with them.

\subsection{Research Procedure}

The intervention group received trainings in infant massage for 4 consecutive days. The trainings were led by instructors and the object of massage was infant phantom. Trainings were carried out simultaneously in the village maternity clinic. Leaflet provided extra information about infant massage.

After giving birth, the mothers got the same trainings for 4 consecutive days. The mothers were asked to massage their babies twice a day- when the babies were taking a bath in the morning and in the afternoon- for the duration of 30 days. The researcher supervised the process of infant massage. Before massage was given, the weight, length, and circumference of the upper arms of the babies were measured. The researcher also interviewed the mothers about the suckling frequency and suckling duration of their babies. The data were recorded in the note book distributed to each mother before.

Meanwhile, the non-intervention group received note book and leaflet. The mothers in this group accepted explanation of how important massage is for their babies. However, they did not receive any training in infant massage. The measurements of baby weight, length, circumference of the upper arms, and suckling frequency and duration were made every week until the fourth week.

\subsection{Infant Massage Technique}

Infant massage took place for 25 minutes. Massage started in the face area, then chest, stomach, arms, legs, and back of the head. Each area was slowly and gently massaged. When giving the massage, the mother maintained eye contact and "communicated" with her baby. A series of massage was done 6 times for 8 seconds each. Baby oil was used for the infant massage.

\subsection{Research Variable}

The research variables in this research are:

a. The body weight of baby was measured with a special weight scale, GEA. The measurement results (in grams) were converted into NCHS category, namely, standard deviation (SD) $<-3$ to $<-2$ and SD -2 to SD 2.

b. The body length of baby was measured with a paper measuring gauge. The measurement results (in centimeters) were converted also into NCHS category, standard deviation (SD) $<-3$ to $<-2$ and SD -2 to SD 2

c. The circumference of the upper arms of baby was measured with an arm gauge for baby, and the measurements were categorized into $>0.5 \mathrm{~cm} /$ month or $<0.5 \mathrm{~cm} /$ month.

d. Suckling frequency of baby was measured during the research period with the categories: $>10$ time suckling frequency /day or $<10$ time suckling frequency/day.

e. Suckling duration of baby was categorized into $>15$ minutes or $<15$ minutes.

\subsection{Data Management and Analysis}

The differences between the research variables before and after intervention in each group and between the intervention and non-intervention groups were compared. All statistical tests were done with $95 \% \mathrm{CI}$.

\subsection{Research Ethics}

Before carrying out this research, the research got an approval from the Research Ethics Commission from Politeknik Kesehatan Kemenkes, Medan beforehand No. 0237/KEPK/POLTEKKES KEMENKES MEDAN/2018. In order to draw information from the respondents, the researcher gave them an informed consent to sign. The informed consent clearly stated that the respondents could leave the research process at any time.

\section{Results}

\subsection{Data of Mother's Demographics and Infant Characteristics in Intervention and Non-Intervention Groups}

This study involved 34 mothers who were in the third trimester of pregnancy. They were divided into two groups. The first group of 17 mothers is the intervention one, while the second group of other 17 mothers were the non-intervention one. All mothers had safe delivery with the total of 19 male babies and 15 female babies. Most female babies $(65 \%)$ were from the non-intervention group. Seen from pregnancy interval and mother parity, the profiles of the two groups were similar. The majority of mothers' latest pregnancy interval was 2 years. Most were multiparous women ( $70.6 \%$ of multiparity in each group). In the intervention group, $64.7 \%$ of mothers were in their $20-\leq 30$ years of age while in the non-intervention group $52.9 \%$ in their $>30$ years of age. 
Table 1. Comparison of Mother's Demographics and Infant Characteristics in Intervention and Non-Intervention Groups

\begin{tabular}{|c|c|c|c|c|}
\hline \multirow{2}{*}{ Characteristics } & \multicolumn{2}{|c|}{ Intervention group } & \multicolumn{2}{|c|}{ Non-intervention group } \\
\hline & $\mathrm{n}$ & $(\%)$ & $\mathrm{n}$ & $(\%)$ \\
\hline \multicolumn{5}{|l|}{ Mother's Age } \\
\hline$>30$ years of age & 6 & 35.3 & 9 & 52.9 \\
\hline $20-\leq 30$ years of age & 11 & 64.7 & 8 & 47.1 \\
\hline \multicolumn{5}{|l|}{ Pregnancy interval } \\
\hline 2 years & 12 & 70.6 & 12 & 70.6 \\
\hline$>2$ years & 5 & 29.4 & 5 & 29.4 \\
\hline \multicolumn{5}{|l|}{ Mother parity } \\
\hline Multiparity & 12 & 70.6 & 12 & 70.6 \\
\hline Grande multiparity & 5 & 29.4 & 5 & 29.4 \\
\hline \multicolumn{5}{|l|}{ Gender of baby } \\
\hline Female & 9 & 53 & 6 & 65 \\
\hline Male & 8 & 47 & 11 & 35 \\
\hline \multicolumn{5}{|c|}{ Birth Weights (in grams) } \\
\hline $2,500-3,000$ & 8 & 47 & 13 & 76 \\
\hline $3,000-3,250$ & 9 & 53 & 4 & 24 \\
\hline \multicolumn{5}{|l|}{ Birth Length (in cm) } \\
\hline $47 \mathrm{~cm}$ & 4 & 24 & 6 & 35 \\
\hline $48 \mathrm{~cm}$ & 5 & 29 & 4 & 24 \\
\hline $49 \mathrm{~cm}$ & 8 & 47 & 7 & 41 \\
\hline \multicolumn{5}{|c|}{ Circumference of uppers arms after birth (in $\mathrm{cm}$ ) } \\
\hline 8 & 2 & 12 & 4 & 24 \\
\hline 8.5 & 4 & 24 & 5 & 29 \\
\hline 9 & 10 & 58 & 7 & 41 \\
\hline 9.5 & 1 & 6 & 1 & 6 \\
\hline
\end{tabular}

Table 2 provides data on the conditions of each group before and after intervention and on the differences of the two groups. Fundamental differences are made by the intervention group. After 4-week intervention, all mean variable values increase significantly. Compared to the conditions before intervention, there are increases in body weight as much as $26.8 \%$, body length as much as $5.2 \%$, circumference of uppers arms as much as $11.8 \%$, suckling frequency as much as $44.7 \%$, and suckling duration as much as $61.6 \%$ after intervention. The main difference occurs in the increasing ability for suckling. All changing conditions are statistically different ( $\mathrm{p}$-value $<0.05$ ).

Different from the babies in the intervention group, the babies in the non-intervention group undergo the following conditions. There are increases in body weight as much as $22 \%$, body length as much as $1 \%$, and circumference of upper arms as much as $11.9 \%$. There are slightly difference in suckling frequency $(13.2 \%)$ and suckling duration (52.4\%). All changing conditions, but body length, in this group have statistical values $(\mathrm{p})<0.05$.

The differences between the intervention group and non-intervention group come up with different statistical test results. For body weight, body length, and suckling frequency variables, the differences are statistically significant $(p<0.05)$, while circumference of upper arms and suckling duration variables do not indicate any difference. 
Table 2. The difference of Mean and SD in the Intervention and Non - Intervention Groups : Before, After and Between Groups

\begin{tabular}{|c|c|c|c|c|}
\hline \multirow{2}{*}{ Variable } & \multicolumn{2}{|l|}{ Intervention group } & \multicolumn{2}{|c|}{ Non-intervention group } \\
\hline & Mean \pm SD & Pvalue & Mean \pm SD & Pvalue \\
\hline \multicolumn{5}{|c|}{ Body weight } \\
\hline Before & $3000.12 \pm 567.28$ & $0.001^{\mathrm{a})}$ & $2941.18 \pm 276.83$ & $0.001^{\mathrm{a})}$ \\
\hline After & $3806.00 \pm 552.79$ & & $3588.24 \pm 270.65$ & \\
\hline$\Delta$ change & $805.88 \pm 105.89$ & & $647.06 \pm 48.25$ & $0.001^{\mathrm{b})}$ \\
\hline \multicolumn{5}{|c|}{ Body length } \\
\hline Before & $48.24 \pm 0.83$ & $0.001^{\text {a) }}$ & $48.06 \pm 0.89$ & $0.445^{\text {a) }}$ \\
\hline After & $50.75 \pm 1.01$ & & $48.54 \pm 0.88$ & \\
\hline$\Delta$ change & $2.51 \pm 0.19$ & & $0.47 \pm 0.05$ & $0.001^{b)}$ \\
\hline \multicolumn{5}{|c|}{ Circumference of upper arms } \\
\hline Before & $8.79 \pm 0.39$ & $0.001^{\text {a) }}$ & $8.17 \pm 2.03$ & $0.007^{\text {a) }}$ \\
\hline After & $9.83 \pm 8.42$ & & $9.16 \pm 2.05$ & \\
\hline$\Delta$ change & $1.04 \pm 0.13$ & & $0.98 \pm 0.13$ & $0.295^{b)}$ \\
\hline \multicolumn{5}{|c|}{ Suckling Frequency } \\
\hline Before & $7.47 \pm 0.51$ & $0.001^{\text {a) }}$ & $7.82 \pm 0.39$ & $0.001^{\text {a) }}$ \\
\hline After & $10.94 \pm 1.39$ & & $8.60 \pm 0.69$ & \\
\hline$\Delta$ change & $3.34 \pm 1.48$ & & $1.04 \pm 1.28$ & $0.001^{\mathrm{b})}$ \\
\hline \multicolumn{5}{|c|}{ Suckling Duration } \\
\hline Before & $9.65 \pm 1.27$ & $0.001^{\text {a) }}$ & $8.71 \pm 0.99$ & $0.007^{\text {a) }}$ \\
\hline After & $15.51 \pm 1.93$ & & $13.09 \pm 2.26$ & \\
\hline$\Delta$ change & $5.95 \pm 2.27$ & & $4.57 \pm 2.32$ & $0.094^{\mathrm{b})}$ \\
\hline
\end{tabular}

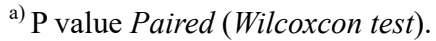

${ }^{b)} \mathrm{P}$ value Independent Sample test/ Mann-Whitney U test. 

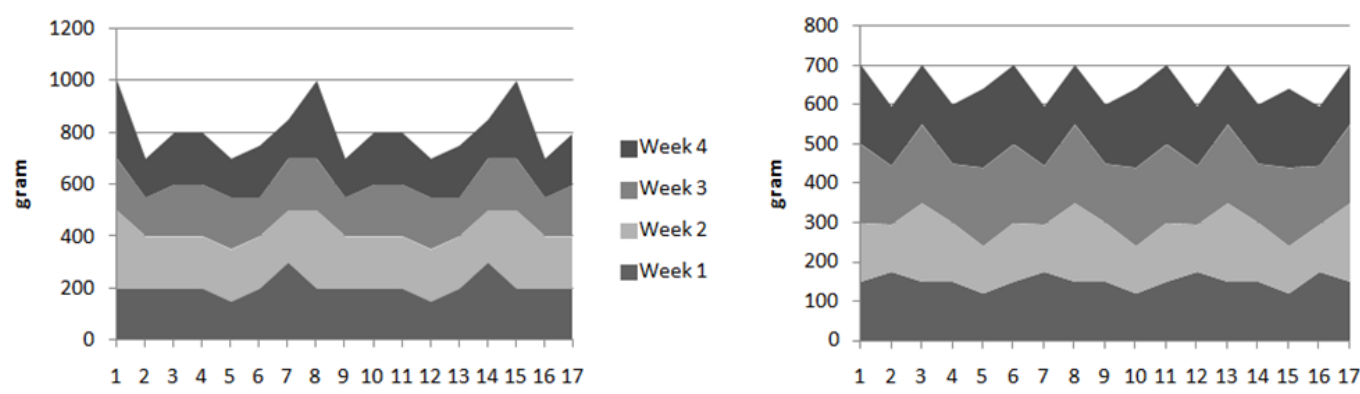

Week 4

Week 4

-Week 3

Week 2

口Week 1

Week 3

Week 2

口Week 1

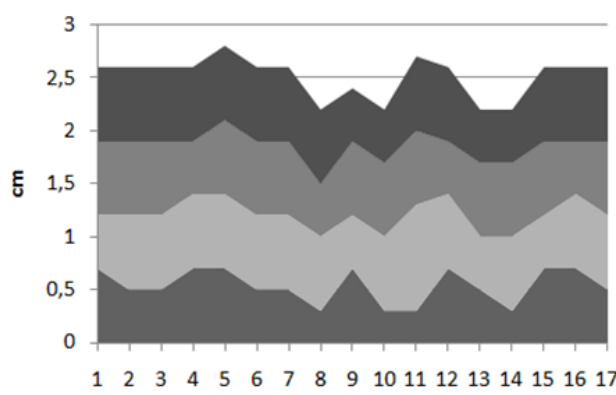

(a) body weight

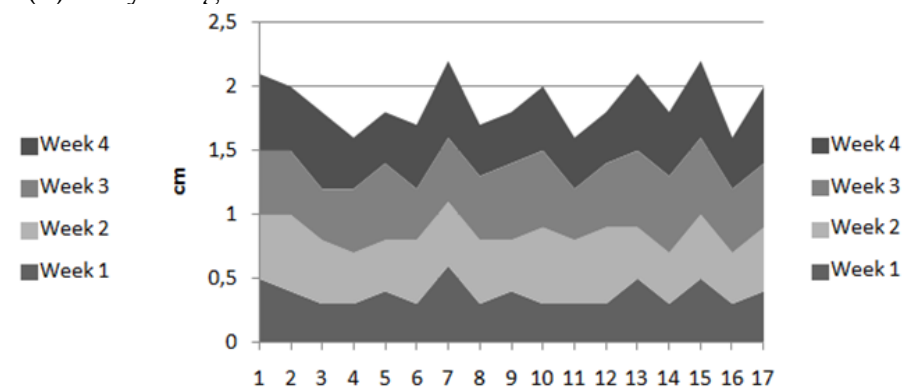

(b) body length
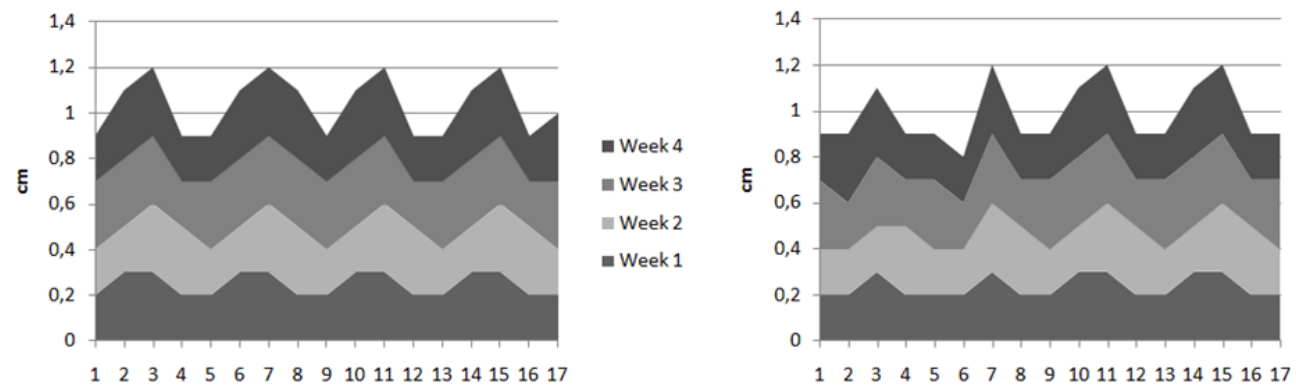

Week 4

-Week 3

-Week 2

- Week 1

(c) circumference of upper arms
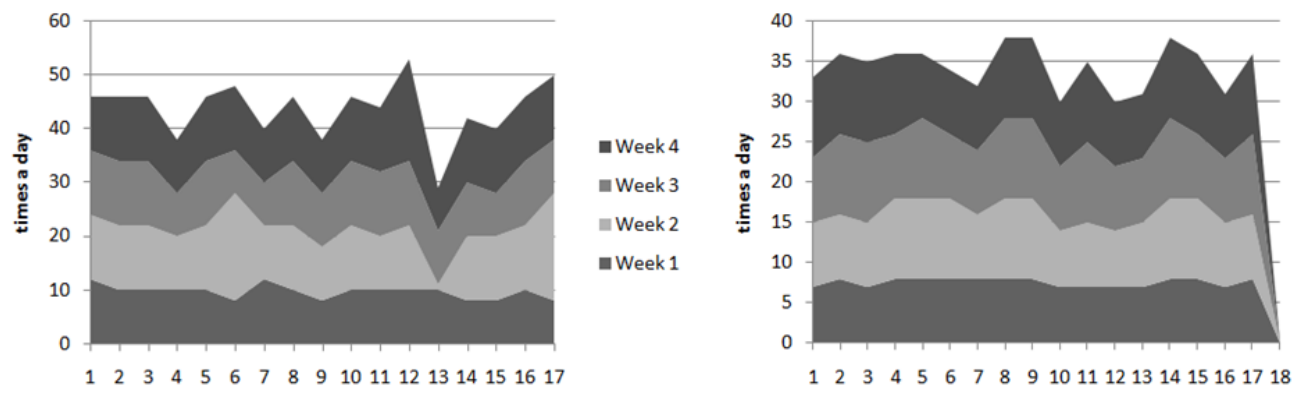

Week 4

- Week 4

-Week 3

week 2

-Week 1

Week 2

Week 1

(d) suckling frequency
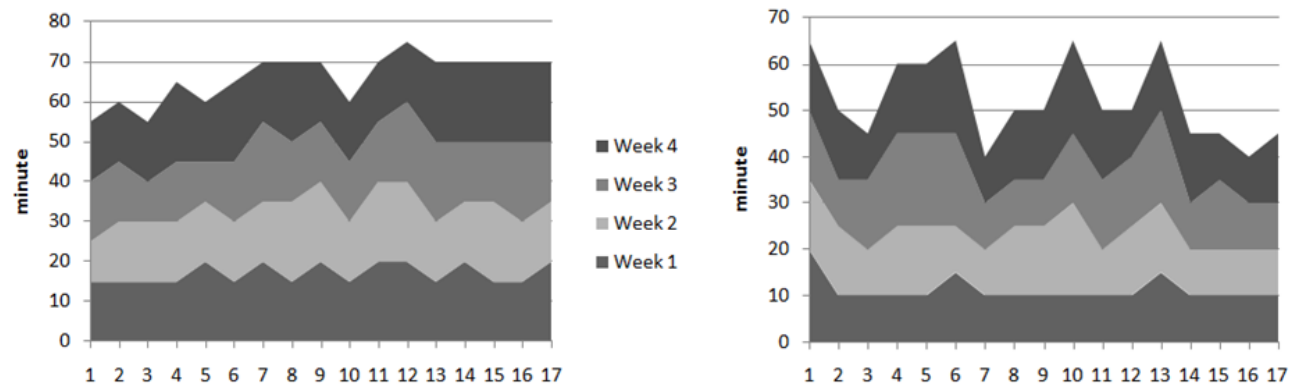

- Week 4

- Week 3

w Week 2

- Week 1

(e) suckling duration

Picture 1. Weekly development of babies in the intervention and non-intervention groups 
The differences between the groups are clearly seen in Picture 1 above. It indicates weekly changes in each variable. Body weights of all babies increase steadily until the third week yet several babies gain significant body weights in the fourth week. The maximum gain weight for several babies in the intervention group is 1000 grams while in the non-intervention group, 700 grams. The same pattern also applies to the body length of the baby. In the first two weeks, the body length reach of the babies in the two groups is relatively the same. However, from the third to the fourth weeks, the babies in the intervention group grow more significantly in body length compared to those in the non-intervention group. Picture 1 part c presents the changes in the circumference of uppers arms. Striking changes are seen in third and then fourth weeks. Suckling frequency and suckling duration of the babies in the intervention groups are much better than those in the non-intervention group when intervention enters the third week.

\section{Discussion}

Educating mothers about infant massage certainly has beneficial effects on their babies. The best time for mothers to receive infant massage education is during the period of entering the third trimester of pregnancy to one month after delivery. Babies having massage undergo physical development in terms of body weight, body length, and circumference of upper arms. They look comfortable during breastfeeding. This condition indirectly create an intimate connection between mother and her baby.

Previous study reveals that after having one-year massage right after their birth, babies record higher scores for motor and mental development. The babies pain responses are low and have shorter LoS (length of stay) in hospital (Abdallah, Kurdahi, \& Hawwari, 2013).

This study also suggests that appropriate infant massage techniques performed by the mother stimulate her baby to gain body weight significantly (Ferber et al., 2002; Lee, 2006). Infant massage and physical exercises could cause rapid weight gain for preterm infants as well (Diego, Field, \& Hernandez-reif, 2014). With massage and physical exercises, babies show significant growth in their bone length as shown in their increasing body length (Field, Diego, \& Hernandez-reif, 2010).

Babies who are given massage have a better sleep quality than those who are not (Field et al., 2016). Babies need to get enough sleep for healthy growth as shown in their increasing body weight and length. This is possible because infant massage improves blood circulation of the baby (Field, Diego, \& Hernandez-reif, 2007). Another hypothesis regarding infant massage is that stroking the muscles of a baby activates a receptor in the baby's body. This receptor is responsible for stimulating effective baby metabolism which in turn promoting rapid physical growth of the baby (Field et al., 2004).

In addition, infant massage seems to be closely related to quality of baby suckling. This study reveals that the suckling frequency and suckling durations of the babies of the mothers in the intervention group are better than those in the non-intervention group (see pictures $1 \mathrm{~d}$ and $1 \mathrm{e}$ ). Weight and length gain of babies do correlate strongly with breastfeeding at least during the early six months of infancy (Küpers et al., 2015).

However, it is important to recognize the psychological effects created by skin-to-skin contact between mother and her baby. This study finds out that mothers who massage their babies in fact establish positive relationships with their babies. These positive relationships maintain the emotional stability of the mothers which in turn stimulates mothers to improve their breast milk production (Gurol \& Polat, 2012). Positively psychological condition allows mothers to produce adequate quantity of milk their babies.

The importance of infant massage has been recognized for a long time (Reissland \& Burghart, 1987; Field, Diego, \& Hernandez-reif, 2007). New studies also confirm that infant massage helps mother to develop affection for her baby (Gurol \& Polat, 2012). It does not only meet the physical needs of the baby but also facilitates both mother and her baby to build positive relationships (Clarke et al., 2002). Compared to the mothers who do not participate in infant massage training, those who join the infant massage trainings for 8 weeks report of better self-confidence in fulfilling their role. The trainings help them to build more intimate and positive relationships with their babies (Vicente, Veríssimo, \& Diniz, 2017). For the mothers, massage could become an activity to channel affection for their babies (Porter et al., 2015). A relaxed emotional state enables mothers to have much better sleep quality (Field et al., 2016).

Like in other cultures, it is the common and traditional role of Indonesian mothers, especially those living in rural areas, to bath their baby. Therefore, mothers do not need to spare specific time to massage their baby since it could be done during bath time because giving infant massage during bath is a natural process a mother could perform (Cooke, 2015). Since many mothers lack adequate knowledge about infant massage techniques (Wati \& Renityas, 2014 ) it is then necessary to train and educate them on infant message from the final phase of their pregnancy to 
one month after giving birth.

\section{Conclusions}

This study proves that infant massage is an effective way to improve baby's physical profiles and suckling quality. It supports the argument that infant massage trainings and education for pregnant women are important to ensure the well-being of both mothers and their babies.

The development and growth of baby are closely related to the baby's relationship with the people around him. This study indicates that as the closest person to her baby, a mother plays a very important role in ensuring the life quality of her baby in the future.

\section{Acknowledgments}

The researcher thanks the Indonesian Ministry of Health for financially supporting this research under the contract number 92.24/PPK/I-Poltekkes Medan/IV/2018.

\section{Competing Interests Statement}

The authors declare that there are no competing or potential conflicts of interest.

\section{References}

Abdallah, B., Kurdahi, L., \& Hawwari, M. (2013). Infant Behavior and Development The efficacy of massage on short and long term outcomes in preterm infants. Infant Behavior and Development. Elsevier Inc., 36(4), 662-669. https://doi.org/10.1016/j.infbeh.2013.06.009

Bagshaw, J., \& Fox, I. (2005). Baby Massage for Dummies. Indianapolis, Indiana: Wiley Publishing, Inc.

Clarke, C. L., Gibb, C., Hart, J., \& Davidson, A. (2002). Infant massage: developing an evidence base for health visiting practice. Clinical Effectiveness in Nursing, 6(3-4), 121-128. https://doi.org/10.1016/S1361-9004(02)00089-4

Cooke, A. (2015) Infant massage: The practice and evidence-base to support it. British Journal of Midwifery, 23(3), 166-170. https://doi.org/10.12968/bjom.2015.23.3.166

Diego, M. A., Field, T., \& Hernandez-reif, M. (2014). Early Human Development Preterm infant weight gain is increased by massage therapy and exercise via different underlying mechanisms. Early Human Development, 90, 137-140. https://doi.org/10.1016/j.earlhumdev.2014.01.009

Ferber, S. G., Kuint, J., Weller, A., Feldman, R., Dollberg, S., Arbel, E., \& Kohelet, D. (2002). Massage therapy by mothers and trained professionals enhances weight gain in preterm infants. Early Human Development, 67(1), 37-45. https://doi.org/10.1016/S0378-3782(01)00249-3

Field, T., Hernandez-Reif, M., Diego, M., Feijo, L., Vera, Y., \& Gil, K. (2004). Massage therapy by parents improves early growth and development. Infant Behavior \& Development, 27(4), 435-442. https://doi.org/10.1016/j.infbeh.2004.03.004

Field, T., Gonzalez, G., Diego, M., \& Mindell, J. (2016). Mothers massaging their newborns with lotion versus no lotion enhances mothers' and newborns' sleep. Infant Behavior \& Development, 45( $\mathrm{Pt} \mathrm{A}), 31-37$. https://doi.org/10.1016/j.infbeh.2016.08.004

Field, T. (2006). Massage therapy research. Developmental Review, 27(1), iv-v. https://doi.org/10.1016/j.dr.2005.12.002

Field, T., Diego, M., \& Hernandezreif, M. (2010). Preterm infant massage therapy research: a review. Infant Behavior \& Development, 33(2), 115-124. https://doi.org/10.1016/j.infbeh.2009.12.004

Ay?e Gürol, \& Polat, S. (2012). The effects of baby massage on attachment between mother and their infants. Asian Nursing Research, 6(1), 35-41. https://doi.org/10.1016/j.anr.2012.02.006

Heath, A., \& Bainbridge, N. (2004). Baby Massage. London: Dorling Kindersley Limited.

Leanne, K. K,, Carianne, L., Bocca, G., Stolk, R. P., Sauer, P. J. J., \& Corpeleijn, E. (2015). Determinants of weight gain during the first two years of life-the gecko drenthe birth cohort. PLOS ONE, 10. https://doi.org/10.1371/journal.pone.0133326

Lee, H. K. (2006). The effects of infant massage on weight, height, and mother-infant interaction. Taehan Kanho Hakhoe Chi, 36(8), 1331. https://doi.org/10.4040/jkan.2006.36.8.1331

MoH. (2019). Basic Health Research 2018. Jakarta. 
Porter, L. S., Porter, B. O., Mccoy, V., Bango-Sanchez, V., Kissel, B., \& Williams, M., et al. (2015). Blended infant massage-parenting enhancement program on recovering substance-abusing mothers $\backslash$ " parenting stress, self-esteem, depression, maternal attachment, and mother-infant interaction. Asian Nursing Research, 9(4), 318-327. https://doi.org/10.1016/j.anr.2015.09.002

Reissland, N., \& Burghart, R. (1987). The role of massage in south asia: child health and development. Social Science \& Medicine, 25(3), 231-239. https://doi.org/10.1016/0277-9536(87)90226-7

The World Bank. (2018). Indonesia Accelerates Fight Against Childhood Stunting, Who We Are/ News. Retrieved from https:/www.worldbank.org/en/news/feature/2018/06/26/indonesia-fights-stunting-commitmentconvergence-and-communities

Vicente, S., Veríssimo, M., \& Diniz, E. (2017). Infant massage improves attitudes toward childbearing, maternal satisfaction and pleasure in parenting. Infant Behavior \& Development, 49, 114. https://doi.org/10.1016/j.infbeh.2017.08.006

Dalili, H., Sheikhi, S., Shariat, M., \& Haghnazarian, E. (2016). Effects of baby massage on neonatal jaundice in healthy iranian infants: a pilot study. Infant Behavior \& Development, 42, 22-26. https://doi.org/10.26699/jnk.v1i1.ART.p052-056

Zaluchu, F. (2006). Metodologi Penelitian Kesehatan. Bandung: Cipta Pustaka Media.

\section{Copyrights}

Copyright for this article is retained by the author(s), with first publication rights granted to the journal.

This is an open-access article distributed under the terms and conditions of the Creative Commons Attribution license (http://creativecommons.org/licenses/by/4.0/). 